\title{
The physicochemical composition of honey from Indonesian stingless bee (Tetragonula laeviceps)
}

\author{
AGUSSALIM $^{1, \boldsymbol{\varphi}}$, NAFIATUL UMAMI ${ }^{1}$, NURLIYANI $^{2}$, ALI AGUS $^{1, \bullet \varphi}$ \\ ${ }^{1}$ Department of Animal Nutrition and Feed Science, Faculty of Animal Science, Universitas Gadjah Mada. J1. Fauna 3 Bulaksumur, Sleman 55281, \\ Yogyakarta, Indonesia. Tel.: +62-878-6515-2543, Fax.: +62-274-521578, "email: agussalim@mail.ugm.ac.id, ^ email: aliagus@ugm.ac.id \\ ${ }^{2}$ Department of Animal Products Technology, Faculty of Animal Science, Universitas Gadjah Mada. J1. Fauna 3, Bulaksumur, Sleman 55281, \\ Yogyakarta, Indonesia
}

Manuscript received: 1 July 2021. Revision accepted: 16 July 2021.

\begin{abstract}
Agussalim, Umami N, Nurliyani, Agus A. 2021. The physicochemical composition of honey from Indonesian stingless bee (Tetragonula laeviceps). Biodiversitas 22: 3257-3263. The demand of honey has recently increased significantly, but this situation is widely used by irresponsible humans who made a fake honey. This present study aims to evaluate the quality based on the physicochemical composition of honey from Indonesian stingless bee Tetragonula laeviceps. Honey was obtained from three geographical origins in Indonesia, i.e. Sleman, Gunungkidul, and Lombok. The physicochemical composition of honey was analyzed such as moisture, ash, protein, $\mathrm{pH}$, glucose/moisture ratio, and electrical conductivity, and amino acids. The results showed that the geographical origins had a highly significant effect $(\mathrm{P}<0.01)$ on moisture, $\mathrm{pH}$, and significant effect $(\mathrm{P}<0.05)$ on ash, electrical conductivity, protein, and glucose/moisture ratio. Honey from Indonesian stingless bee T. laeviceps was found 17 amino acids were arginine, histidine, lysine, phenylalanine, isoleucine, leucine, methionine, valine, threonine, tyrosine, proline, glutamic acid, aspartic acid, serine, alanine, glycine, and cysteine. The dominant amino acids of honey from Sleman were glutamic acid, histidine, lysine, and arginine. Honey from Lombok were glutamic acid, aspartic acid, lysine, and histidine. Furthermore, honey from Gunungkidul were lysine, arginine, histidine, and phenylalanine. Honey from Sleman and Lombok have the best quality than honey from Gunungkidul based on the chemical composition and amino acids profile.
\end{abstract}

Keywords: Adulteration, klanceng honey, LC-MS/MS, nectar, pollen

\section{INTRODUCTION}

The number of stingless bees in Indonesia at least 46 species spread in several islands such as Sumatera, Borneo, Java, Sulawesi, Timor, Ambon, Maluku, and Papua (Kahono et al. 2018). Furthermore, in Yogyakarta are found 7 species as the local stingless bee consists of Tetragonula laeviceps, T. biroi, T. sapiens, T. iridipennis, T. sarawakensis, Lepidotrigona terminata, and Heterotrigona itama (Trianto and Purwanto 2020). T. laeviceps can be found in tropical areas including Indonesia. In Indonesia, stingless bees are known as Trigona bee especially by beekeepers, but the Trigona species does not exist in Indonesia, and in Java is called Klanceng bee. T. laeviceps have a natural habitat in the trunk of trees or woods, bamboo, sugar palm stalks, and in the ground (Agussalim 2015; Agus et al. 2019; Agussalim et al. 2019). Stingless bee T. laeviceps can produce honey, bee bread, and propolis (Agussalim et al. 2019, 2020; Erwan et al. 2020, 2021; Sabir et al. 2021).

The demand of honey has recently increased significantly, especially during the pandemic of Covid-19. However, this situation is widely used by irresponsible humans who made a fake honey to obtain profit despite endangering the consumers health because very low quality. Honey is a natural food that is produced by the worker bees from nectar as the raw material. Honey is composed by sugars, amino acids, enzymes, carotenoids, minerals, organic acids, aromatic compounds, and vitamins
(Da Silva et al. 2016). Honey from Indonesian stingless bee T. laeviceps is low in sugar content (Agussalim et al. 2019) and high in phenolic content, flavonoid content, and antioxidant activity (Agus et al. 2019). The chemical composition of honey from stingless bee species from the various country have been studied (Souza et al. 2006; Oddo et al. 2008; Guerrini et al. 2009; Suntiparapop et al. 2012; Biluca et al. 2016; Chuttong et al. 2016; Ranneh et al. 2018; Villacrés-Granda et al. 2021), but in Indonesia has not yet studied as comprehensive from Lombok (West Nusa Tenggara), Sleman, and Gunungkidul (Yogyakarta).

The amino acids present in honey from Apis mellifera consists of proline, glutamine, glutamic acid, glycine, aspartic acid, arginine, histidine, tyrosine, threonine, methionine, butyric acid, lysine, valine, leucine, cysteine, asparagine, tryptophan, isoleucine, alanine, phenylalanine, serine, and ornithine (Hermosín et al. 2003; Iglesias et al. 2006; Rebane and Herodes 2010; Kečkeš et al. 2013; Truzzi et al. 2014; Da Silva et al. 2016). Furthermore, reported that honey from Brazilian stingless bee is found 16 of amino acids consists of arginine, aspartic, asparagine, glutamine, serine, glutamic, glycine, threonine, alanine, proline, tyrosine, valine, leucine, isoleucine, phenylalanine, and tryptophan (Biluca et al. 2019), but the amino acids of honey from Indonesian stingless bee has not been studied. This present study aims to evaluate the quality based on the physicochemical composition of honey from Indonesian stingless bee $T$. laeviceps. 


\section{MATERIALS AND METHODS}

\section{Study area}

The honey was collected directly from the artisanal hives of stingless bee beekeepers when dry season from three geographical origins in Indonesia (each location was three samples), i.e. Sleman (Faculty of Animal Science, Universitas Gadjah Mada), Gunungkidul (Ngrandu, Katongan Village, Nglipar Sub-district), and North Lombok (Lendang Gagak, Sukadana Village, Bayan Subdistrict) was shown in Figure 1.

\section{Procedures}

Physicochemical composition of honey

The moisture, ash, and protein were determined using proximate analysis (AOAC 2005). The $\mathrm{pH}$ was measured using a $\mathrm{pH}$ meter and briefly, honey $10 \mathrm{~g}$ was diluted in $100 \mathrm{~mL}$ aquadest $(10 \% \mathrm{w} / \mathrm{v})$ using beaker glass, then was mixed using a vortex, and then $\mathrm{pH}$ was measured. The glucose/moisture ratio was determined based on the glucose content divided by moisture. The electrical conductivity was determined by the equation $\mathrm{EC}=$ $0.14+1.74 \mathrm{~A}$ (where $\mathrm{A}$ is the ash content) (Piazza et al. 1991). All analyses were carried out in three replicates, each in duplo.

The amino acids profile of honey was determined using liquid chromatography mass spectrometry (LCMS/MS) method according to Kowalski et al. (2017) with minor modification. Briefly, honey for about $2 \mathrm{~g}$ was added to the erlenmeyer flask $50 \mathrm{~mL}$, then $20 \mathrm{~mL}$ of $\mathrm{HCl} 6 \mathrm{~N}$ was added and the solution was vortexed for 2 minutes. The solution was hydrolyzed in an autoclave with the temperature $100^{\circ} \mathrm{C}$ for 12 hours. The solution was neutralized with $50 \mathrm{~mL}$ of $\mathrm{NaOH} 6 \mathrm{~N}$, then vortexed and the solution was filtered using $0.22 \mu \mathrm{M}$. The separation was achieved with Purospher Star RP-8ec column $(150 \mathrm{~mm}$ x $4.6 \mathrm{~mm} \times 3$ $\mu \mathrm{m})$. Afterwards, the solution was diluted again 10 times and then taken $2 \mu \mathrm{L}$ to be injected into LCMS/MS. Mobile phase condition when LCMS/MS operated were $\mathrm{A}=0.1 \%$ pentadecafluorooctanoic acid 99.5\%:0.5\% water $/ \mathrm{CH}_{3} \mathrm{CN}$ with $0.1 \%$ formic acid; $\mathrm{B}=0.1 \%$ pentadecafluorooctanoic acid, $10 \%: 90 \%$ for water: $\mathrm{CH}_{3} \mathrm{CN}$ with $0.1 \%$ formic acid. Flow $=0.6 \mathrm{~mL} /$ minutes, injected volume was $2 \mu \mathrm{L}$, capillary $3.50 \mathrm{kV}$, desolvation temperature $500^{\circ} \mathrm{C}$, dislocation 1,000 liters/hour, and collision energy $15.00 \mathrm{~V}$. The analysis was carried out in one sample (three samples each location was mixed in one sample used in this study) each in duplo. The gradient condition when LCMS/MS operated was shown in Table 1.

Table 1. The gradient condition of LCMS/MS when operated to an analysis of amino acids

\begin{tabular}{ccc}
\hline Time & \% A & \% B \\
\hline Initial & 90.00 & 10 \\
5.00 & 50.00 & 50 \\
5.20 & 90.00 & 10 \\
7.00 & 90.00 & 10 \\
\hline
\end{tabular}

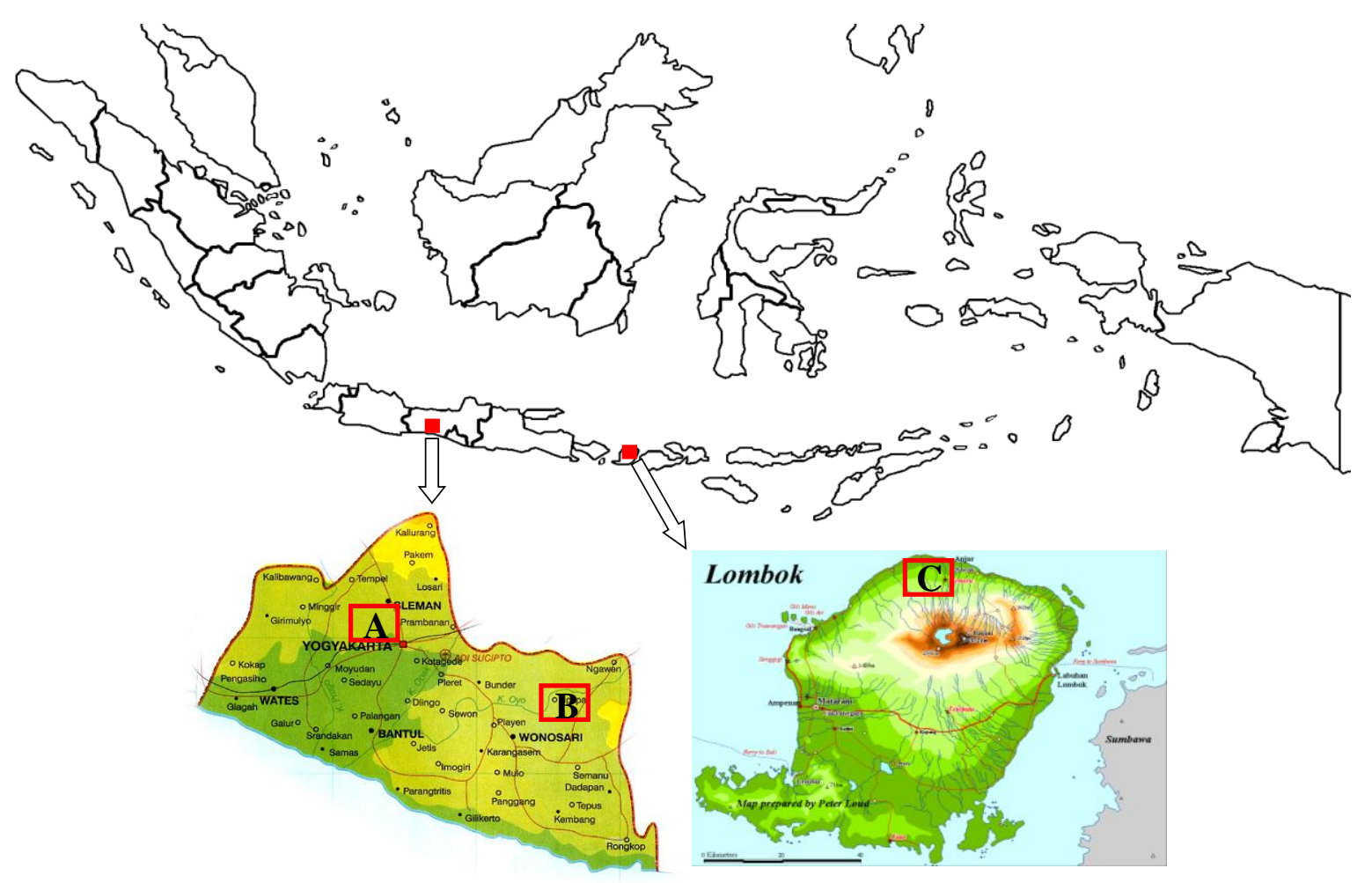

Figure 1. The geographical origins were used to collect honey samples were Sleman (A: 746'09'S 110²3'10'E), Gunungkidul (B:

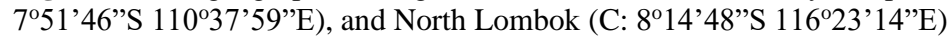




\section{Plant types as stingless bee forages}

The plant types as the nectar source for stingless bee $T$. laeviceps in each region also was identified with maximum radius was 300 meters. Briefly, plant flowers were taken, and then the availability of nectar was checked by opening the flower petals, then checking the liquid content was indicated as the nectar in the base (Agussalim et al. 2017, 2018) and also based on the information from previous studies. In our study, to identify the plant types as the nectar source not used melissopalynology method but based on the dept discussion with beekeepers about the flowers blooming when 2 to 3 months previously to determine the dominant plant types as the nectar source.

\section{Data analysis}

The chemical composition of honey was analyzed with a one-way analysis of variance (ANOVA) using SPSS (Windows version of SPSS, release 23). Significant differences between the means were identified by honestly significant difference tests, while amino acids of honey and the plant types as the nectar source from each region were analyzed by descriptive analysis.

\section{RESULTS AND DISCUSSION}

\section{Physicochemical composition of honey}

The different geographical origins of honey affected on the different plant types (Table 2) as the nectar source to produce honey. In addition, the different geographical origins had a highly significant effect $(\mathrm{P}<0.01)$ on moisture, $\mathrm{pH}$ and had a significant effect $(\mathrm{P}<0.05)$ on ash, glucose/moisture ratio, protein, and electrical conductivity of honey (Figure 2 and 3). Moisture is the second large component after sugars present in honey and one of the criteria to determine the quality of honey. In addition, moisture is one of the very important parameters that influence honey physical properties such as crystallization, color, flavor, taste, and solubility (Escuredo et al. 2013; Da Silva et al. 2016). The moisture of honey from Sleman and Lombok were not differ and both were higher than honey from Gunungkidul because the geographical conditions (temperature and humidity) and honey maturity level each location is different. The honey moisture from Indonesian stingless bee T. laeviceps was ranged from 19.49 to $23.58 \%$.

The high temperature with low humidity will influence the nectar with low moisture and high in sugar content, but low temperature with high humidity impact on nectar with high moisture and low sugar content. The high and lower nectar moisture is related to the hygroscopic properties of sugar in nectar because it absorbs more water from the moist air than dry air. Furthermore, Bogdanov et al. (2004) explained that honey moisture is influenced by season, climate, plant types (mono-floral or multi-floral) so can affect the honey physical properties such as crystallization, viscosity, and glucose/moisture ratio, however the viscosity not studied. However, the honey moisture can be changed when a manipulation process such as heating or evaporation process. The honey moisture in our study (Figure 2) is acceptable by the Indonesian national standard for stingless bees honey not to exceed 27.5\% (SNI 2018).

Generally, honey from stingless bees is higher in moisture than honey from honeybee species, because the foragers from the stingless bee is collecting nectar, material from ripe fruit with the high in moisture (Guerrini et al. 2009; Suntiparapop et al. 2012). In addition, in honeybees A. mellifera has developed several behavior mechanisms to evaporate water, but the stingless bees can't do it (Suntiparapop et al. 2012). The honey moisture from Indonesian stingless bee T. laeviceps (Figure 2) is lower than those previously studied (Souza et al. 2006; Oddo et al. 2008; Guerrini et al. 2009; Suntiparapop et al. 2012; Biluca et al. 2016; Chuttong et al. 2016; Ranneh et al. 2018). Da Silva et al. (2016) explained that honey moisture is affected by geographical origins, plant types as the nectar source, season, or climate (temperature and humidity), honey maturity level, processing postharvest (heating and manipulation), and storage time.

The ash content in honey is used as the one indicators to evaluate the mineral content in honey which collected by foragers from nectar (floral), honeydew, and extrafloral nectar of plant (Suntiparapop et al. 2012; Da Silva et al. 2016), however in our study has not studied. Sabir et al. (2021) explained that the ash content of honey is positively correlate with mineral content. In addition, also describes the pollution of environmental and geographical origins because its content is depended on the type of soil an area to planted a plant as the stingless bee or honeybee forages (Karabagias et al. 2014; Da Silva et al. 2016). The ash content of honey from Sleman and Lombok were did not differ and higher than honey from Gunungkidul (Figure 3). The ash content from Indonesian stingless bee T. laeviceps was ranged from 0.12 to $0.79 \mathrm{~g} / 100 \mathrm{~g}$ of honey. The different ash content of honey from each origin is affected by the different in plant types as the nectar source (Table 2 ), type, and soil condition is related to the availability of soil nutrients.

Table 2. Predominant plant types as the nectar source to produce honey from different geographical origins

\begin{tabular}{lll}
\hline Sleman & Lombok & Gunungkidul \\
\hline Banana (Musa paradisiaca L.) & Coconut (Cocos nucifera) & Calliandra (Calliandra calothyrsus) \\
Rambutan (Nephelium lappaceum) & Mango (Mangifera indica) & Mexican creeper (Antigonon leptopus) \\
Canarium (Canarium indicum L.) & Kapok (Ceiba pentandra) & Banana (Musa paradisiaca L.) \\
Tamarind (Tamarindus indica) & Cashew (Anacardium occidentale) & Mango (Mangifera indica) \\
Matoa (Pometia pinnata) & - & White albizia (Paraserianthes falcataria) \\
Cattapa (Terminalia catappa) & - & - \\
\hline
\end{tabular}




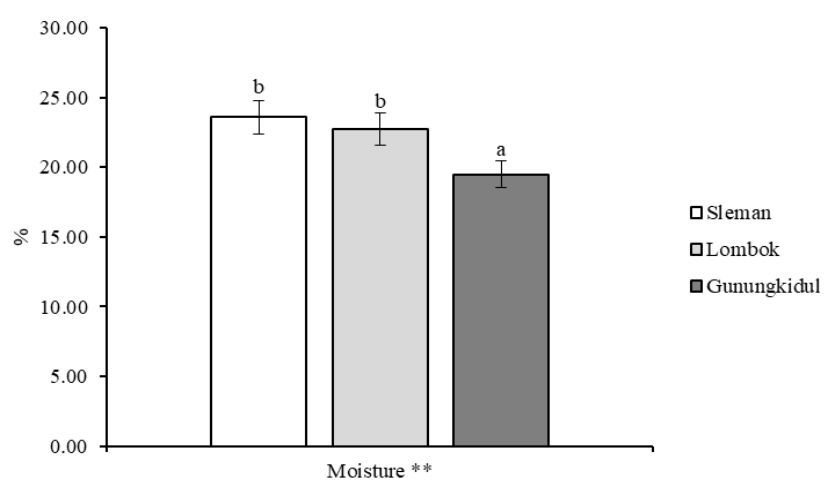

Figure 2. The moisture of honey from Indonesian stingless bee $T$. laeviceps from different geographical origins (**significant at $\mathrm{P}<0.01)$

In addition, the mineral content of honey is related to color, flavor, and aroma. The high mineral content causes dark color honey and a stronger aroma than light honey (Escuredo et al. 2013; Karabagias et al. 2014; Da Silva et al. 2016). This condition is found in honey from Sleman and Lombok with a dark color and stronger aroma than honey from Gunungkidul with bright color and the usual aroma. The ash content of honey from Indonesian stingless bee $T$. laeviceps is acceptable by Indonesian national standard not to exceed $0.5 \%$ for stingless bees honey (SNI 2018), except honey from Lombok. In addition, the ash content of honey from Indonesian stingless bee T. laeviceps (Figure 3) is differ to those previously studied (Souza et al. 2006; Oddo et al. 2008; Suntiparapop et al. 2012; Chuttong et al. 2016; Ranneh et al. 2018; Villacrés-Granda et al. 2021). The ash content is affected by plant types as the nectar source and geographical origins which impact on the different soil nutrients, and influence the mineral content of nectar (Karabagias et al. 2014; Da Silva et al. 2016). The conductivity of electrical honey from Sleman and Lombok did not differ and both were higher than honey from Gunungkidul. The electrical conductivity of honey from Indonesian stingless bee $T$. laeviceps was ranged from 0.34 to $1.51 \mathrm{mS} / \mathrm{cm}$. The honey electrical conductivity is related to ash content (minerals content), organic acids, acidity, and ions presence (Da Silva et al. 2016). The electrical conductivity of honey from Gunungkidul is acceptable by an international standard not to exceed $0.80 \mathrm{mS} / \mathrm{cm}$ (Da Silva et al. 2016), but honey from Sleman and Lombok not acceptable.

The honey $\mathrm{pH}$ from 3.2 to 4.5 with the natural acidity can inhibit the microorganism growth where the optimum $\mathrm{pH}$ for they growth is ranged from 7.2 to 7.4 (SuárezLuque et al. 2002; Karabagias et al. 2014; Da Silva et al. 2016). Honey from Sleman and Lombok did not differ in $\mathrm{pH}$, but the $\mathrm{pH}$ of honey from Lombok is lower than honey from Gunungkidul. However, the $\mathrm{pH}$ of honey from Sleman and Gunungkidul were did not differ (Figure 3). The $\mathrm{pH}$ values of honey from Indonesian stingless bee $T$. laeviceps was ranged from 3.85 to 4.14 . Honey from each geographical origin has a different flavor such as sweet dominant for honey from Sleman, sweet mixed with sour for honey from Lombok, and sweet mixed bitter for honey from Gunungkidul.

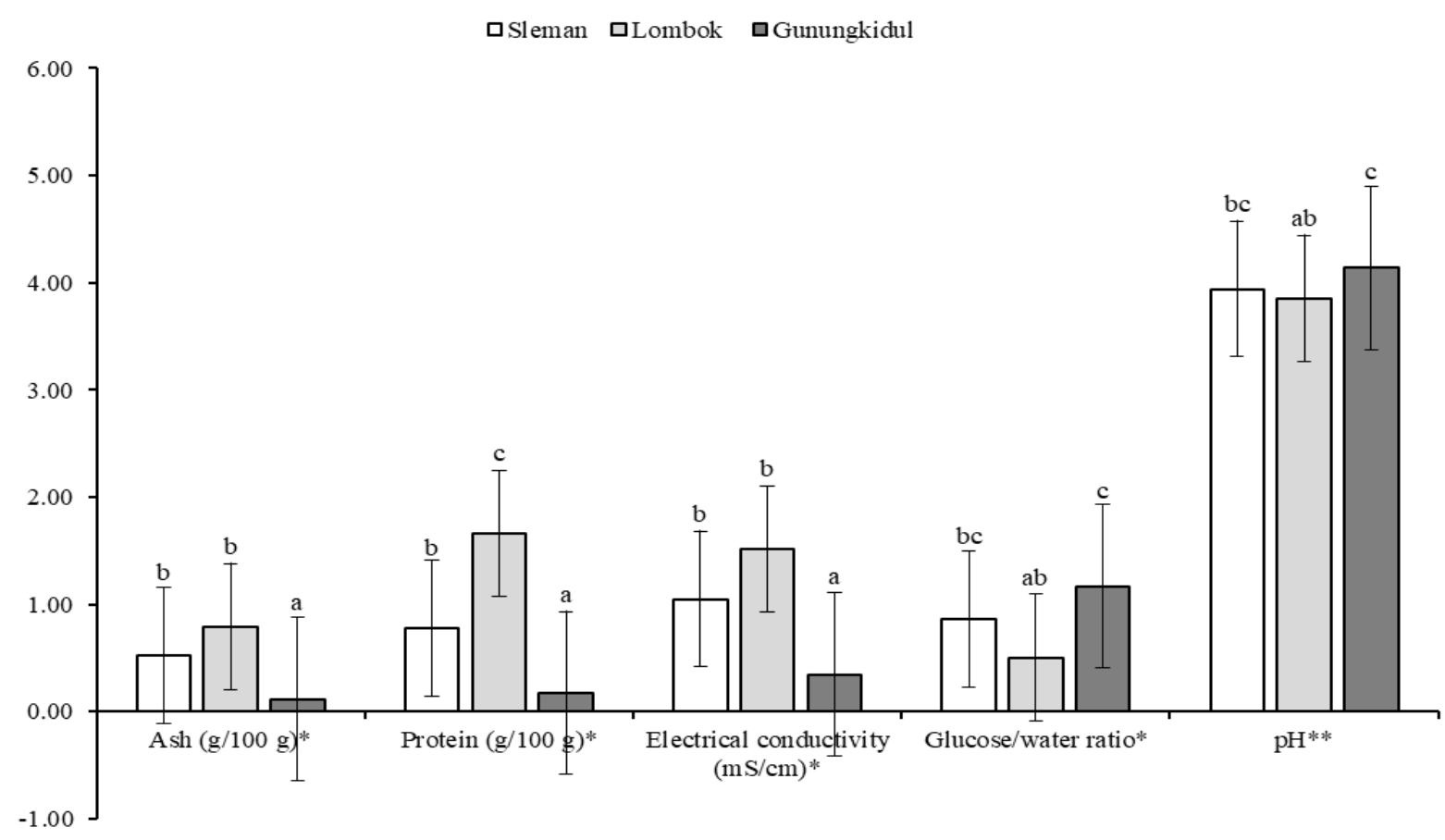

Figure 3. The chemical composition of honey from Indonesian stingless bee $T$. laeviceps from different geographical origins (**significant at $\mathrm{P}<0.01$, *significant at $\mathrm{P}<0.05$ ) 
The acidity and $\mathrm{pH}$ are used as the parameters to determine the honey quality, fresh level of honey, and related to antimicrobial properties. The high acidity and low $\mathrm{pH}$ are indicated the fermentation process of sugars in honey that impact on organoleptic characteristic and honey quality (Alvarez-Suarez et al. 2018). In addition, the $\mathrm{pH}$ in some cases used to verify the adulteration of honey ( $\mathrm{Da}$ Silva et al. 2016), but in our study using pure honey. Ribeiro et al. (2014) reported that honey added with corn syrup (high in fructose) is caused an increased in honey $\mathrm{pH}$ significantly than pure honey. The honey $\mathrm{pH}$ from Indonesian stingless bee T. laeviceps in our study (Figure 3 ) is differ to those previously studied for stingless bees honey (Souza et al. 2006; Suntiparapop et al. 2012; Biluca et al. 2016). The different honey $\mathrm{pH}$ is affected by stingless bee species, plant types as the nectar source, honey maturity level, and geographical origins (Da Silva et al. 2016).

The glucose/moisture ratio is one of the indicators used as the criteria to predict the crystallization process from honey (Dobre et al. 2012). The glucose/moisture ratio of honey from Sleman and Lombok were did not differ, but both are lower than honey from Gunungkidul (Figure 3). The glucose/moisture ratio of honey from Indonesian stingless bee $T$. laeviceps was ranged from 0.50 to 1.17 . Dobre et al. (2012) explained that higher in glucose and lower moisture is caused honey to rapidly crystallization because the value of glucose/moisture ratio is bigger. Honey with glucose/moisture ratio under 1.7 is slower and does not crystalize, while honey with glucose/moisture ratio is above 2 will be rapidly crystallized. The honey from Indonesian stingless bee T. laeviceps (Figure 3) does not crystalize despite has been stored for 2 years because the glucose/moisture ratio in our study under 1.7 . The glucose/moisture ratio of honey from the Indonesian stingless bee T. laeviceps in our study (Figure 3) is differ with reported by Dobre et al. (2012) for various honey from A. mellifera such as linden honey is ranged from 1.3 to 2.4 , rape honey 1.4 to 2.9 , sun-flower honey 1.5 to 1.9 , multifloral honey 1.3 to 2.0 , and honeydew 1.2 to 2.0 . The different of glucose/moisture of honey is affected by plant types as the nectar source, glucose and moisture content from each honey, honeybee or stingless bee species, and geographical origins (Da Silva et al. 2016). The recent study reported that the different of geographical origins and stingless bee species (12 species) are influencing moisture, ash, $\mathrm{pH}$, and electrical conductivity (Villacrés-Granda et al. 2021), however in our study from the same species.

\section{Amino acids profile}

The protein and amino acids present in honey are originated from nectar and honeydew (Sak-Bosnar and Sakač 2012; Escuredo et al. 2013; Da Silva et al. 2016), but the main source is pollen ( $\mathrm{Da}$ Silva et al. 2016). The protein contains the amino acids and the relative proportion is depending on forages such as nectar, honeydew, and pollen (Da Silva et al. 2016). Honey from Lombok is higher in protein content, followed by honey from Sleman, and the lowest protein content is honey from Gunungkidul (Figure 3). The protein content of honey from Indonesian stingless bee $T$. laeviceps was ranged from 0.17 to 1.66 $\mathrm{g} / 100 \mathrm{~g}$ of honey. The different protein content of each honey is affected by the different plant types as the nectar source (Table 2). In addition, when honey is harvested might be pot pollen (bee bread) is attached to the pot honey is also harvested so it influences the protein content of honey. The protein content of honey from Indonesian stingless bee $T$. laeviceps (Figure 3 ) is differ to those previously studied for stingless bee honey (Souza et al. 2006; Ranneh et al. 2018; Villacrés-Granda et al. 2021). The different protein content of honey is affected by plant types as the nectar and pollen sources, honeybee or stingless bee species, and geographical origins (Da Silva et al. 2016).

In honey from A. mellifera, the abundance of amino acids is proline for about 50 to $85 \%$ of the amino acids total. The proline amino acid is originated and secreted by saliva and hypopharyngeal glands during the nectar conversion into honey (Iglesias et al. 2006; Truzzi et al. 2014; Da Silva et al. 2016). Furthermore, the amino acids in honey such as glutamine, glycine, glutamic acid, tryptophan, histidine, arginine, leucine, tyrosine, alanine, aspartic acid, ornithine, isoleucine, methionine, lysine, threonine, butyric acid, valine, cysteine, serine, phenylalanine, and asparagine (Hermosín et al. 2003; Rebane and Herodes 2010; Kečkeš et al. 2013; Da Silva et al. 2016).

The present results showed that the amino acids in honey from Indonesian stingless bee T. laeviceps have been detected by LCMS/MS are 17 amino acids, but the cysteine is not detected in honey from Sleman and Gunungkidul (Table 3). The total of amino acids content was higher in honey from Lombok was $10,941.6 \mathrm{mg} / \mathrm{kg}$ followed by honey from Sleman was $7,760.5 \mathrm{mg} / \mathrm{kg}$ and the lowest in honey from Gunungkidul was $3,008.5 \mathrm{mg} / \mathrm{kg}$. The amino acids in honey are positively correlated with the protein content of each region. The protein content of honey from Lombok was higher followed by honey from Sleman and the lowest was honey from Gunungkidul (Figure 3).

Tabel 3. The amino acids profile of honey from Indonesian stingless bee $\mathrm{T}$. laeviceps from different geographical origins

\begin{tabular}{llll}
\hline \multirow{2}{*}{$\begin{array}{c}\text { Amino acids } \\
\text { content } \\
(\mathbf{m g} / \mathbf{K g})\end{array}$} & \multicolumn{1}{c}{ Gleman } & \multicolumn{1}{c}{ Lombok } & \multicolumn{1}{c}{ Gunungkidul } \\
\cline { 2 - 4 } & \multicolumn{1}{c}{ Geographical origins } \\
\hline Arginine & $922.24 \pm 24.04$ & $924.38 \pm 133.26$ & $550.74 \pm 27.18$ \\
Histidine & $1,048.07 \pm 126.78$ & $1,230.35 \pm 455.64$ & $476.55 \pm 120.05$ \\
Lysine & $1,012.06 \pm 233.51$ & $1,252.43 \pm 136.63$ & $766.20 \pm 126.22$ \\
Phenylalanine & $798.78 \pm 18.74$ & $353.50 \pm 36.96$ & $324.69 \pm 2.63$ \\
Isoleucine & $191.29 \pm 2.89$ & $291.26 \pm 34.46$ & $14.76 \pm 1.64$ \\
Leucine & $495.94 \pm 107.83$ & $662.39 \pm 51.33$ & $75.19 \pm 10.48$ \\
Tyrosine & $70.64 \pm 4.82$ & $89.22 \pm 0.03$ & $10.74 \pm 1.15$ \\
Methionine & $64.11 \pm 1.03$ & $58.53 \pm 14.57$ & not detected \\
Valine & $192.90 \pm 5.05$ & $417.35 \pm 7.56$ & $27.55 \pm 0.87$ \\
Proline & $267.82 \pm 14.37$ & $597.84 \pm 1.94$ & $80.54 \pm 3.55$ \\
Glutamic acid & $1,238.74 \pm 15.04$ & $1,922.98 \pm 18.63$ & $150.20 \pm 42.49$ \\
Aspartic acid & $410.74 \pm 1.98$ & $1,364.41 \pm 86.35$ & $84.45 \pm 22.16$ \\
Cysteine & $n o t$ detected & $15.66 \pm 12.61$ & not detected \\
Threonine & $169.15 \pm 15.60$ & $342.15 \pm 33.35$ & $33.52 \pm 17.93$ \\
Serine & $472.48 \pm 84.61$ & $593.26 \pm 85.40$ & $275.93 \pm 133.61$ \\
Alanine & $239.23 \pm 21.70$ & $475.90 \pm 0.40$ & $71.56 \pm 13.83$ \\
Glycine & $166.31 \pm 25.12$ & $349.95 \pm 21.83$ & $65.88 \pm 57.11$ \\
Total & $7,760.50$ & $10,941.57$ & $3,008.50$ \\
\hline
\end{tabular}

Note: Honey sample was analyzed in duplo and the data are presented as the means \pm standard deviation 
The amino acids of honey from Sleman were dominant in glutamic acid, histidine, lysine, and arginine. In honey from Lombok were glutamic acid, aspartic acid, lysine, and histidine. Furthermore, honey from Gunungkidul were lysine, arginine, histidine, and phenylalanine, but for all amino acids of honey from Gunungkidul was lower than honey from Sleman dan Lombok. In honey from Brazilian stingless bees, it has been reported that histidine amino acid is less than the limit of detection for all regions (Biluca et al. 2019), but in our study, it's one of the dominant amino acids.

In addition, these results is differ from previously reported that the dominant amino acids from stingless bee honey were phenylalanine (Biluca et al. 2019) and proline (Biluca et al. 2019; Villacrés-Granda et al. 2021), while proline in our study was lower and not dominant. It indicates that the different geographical origins, and plant types as the nectar source affect the amino acids content of honey (Biluca et al. 2019; Villacrés-Granda et al. 2021), stingless bee species (Villacrés-Granda et al. 2021), and pollen source however in our study not studied and also using same species of stingless bee.

The proline amino acid has been used as the one of criteria to evaluate the maturity and adulteration of honey (Bogdanov et al. 1999; Da Silva et al. 2016). In A. mellifera, the minimum of proline amino acid content that can be acceptable for pure honey is $180 \mathrm{mg} / \mathrm{kg}$ of honey (Bogdanov et al. 1999; Hermosín et al. 2003; BentabolManzanares et al. 2014; Da Silva et al. 2016), however in stingless bee honey has not regulated. Honey from Sleman and Lombok were acceptable for pure and mature honey, but honey from Gunungkidul is lower than the standard. The amino acids content of honey from Indonesian stingless bee $T$. laeviceps (Table 3 ) is differ from previously studied for stingless bee honey (Biluca et al. 2019) and honey from A. mellifera (Belay et al. 2017; Kowalski et al. 2017; Sun et al. 2017). The difference in amino acids content of honey is caused by the difference of stingless bee species, the plant types as the bee forages (nectar and pollen), and geographical origins (Da Silva et al. 2016). The recent study reported that the different of geographical origins and stingless bee species (12 species) are influencing protein and amino acids especially in proline and leucine (Villacrés-Granda et al. 2021), however in our study from the same species. This study showed that the different geographical origins is influencing the physicochemical composition of honey from Indonesian stingless bee $T$. laeviceps. Thus, it can be concluded that the honey from Sleman and Lombok have the best quality than honey from Gunungkidul based on the physicochemical composition. The dominant amino acids of honey from Indonesian stingless bee $T$. laeviceps such as glutamic acid, histidine, lysine, arginine, and aspartic acid.

\section{ACKNOWLEDGEMENTS}

The authors would like to thank the Directorate of Research and Community Service, Ministry of Education, Culture, Research, and Technology of the Republic of
Indonesia for financial support of the research through Penelitian Terapan Unggulan Perguruan Tinggi (PTUPT) and Penelitian Disertasi Doktor (PDD).

\section{REFERENCES}

Agus A, Agussalim, Nurliyani, Umami N, Budisatria IGS. 2019. Evaluation of antioxidant activity, phenolic, flavonoid and vitamin $\mathrm{C}$ content of several honeys produced by the Indonesian stingless bee: Tetragonula laeviceps. Livest Res Rural Dev 31(10): 152

Agussalim A, Agus A, Umami N, Budisatria IGS. 2017. Variation of honeybees forages as source of nectar and pollen based on altitude in Yogyakarta. Bull Anim Sci 41 (4): 448-460. DOI: 10.21059/buletinpeternak.v41i4.13593.

Agussalim A, Agus A, Umami N, Budisatria IGS. 2018. The type of honeybees forages in Sub-district of Pakem, Sleman and Nglipar, Gunungkidul, Yogyakarta. Bull Anim Sci 42 (1): 50-56. DOI: 10.21059/buletinpeternak.v42i1.28294.

Agussalim, Agus A, Nurliyani, Umami N. 2019. The sugar content profile of honey produced by the Indonesian stingless bee, Tetragonula laeviceps, from different regions. Livest Res Rural Dev 31 (6): 91

Agussalim, Nurliyani, Umami N, Agus A. 2020. The honey and propolis production from Indonesian stingless bee: Tetragonula laeviceps. Livest Res Rural Dev 32 (8): 121.

Agussalim. 2015. Production of Honey, Pollen and Propolis of Stingless Bee Trigona sp. in Various Beehive Design. [Tesis]. Universitas Gadjah Mada, Yogyakarta. [Indonesian].

Alvarez-Suarez JM, Giampieri F, Brenciani A, Mazzoni L, Gasparrini M, González-Paramás AM, Santos-Buelga C, Morroni G, Simoni S, Forbes-Hernández TY, Afrin S, Giovanetti E, Battino M. 2018. Apis mellifera vs Melipona beecheii Cuban polifloral honeys: A comparison based on their physicochemical parameters, chemical composition and biological properties. LWT - Food Sci Technol 87: 272-279. DOI: 10.1016/j.lwt.2017.08.079.

AOAC. 2005. Official Method of Association of Official Analytical Chemist. 18th Edition. Association of Official Analytical Chemist. Benjamin Franklin Station, Washington D.C.

Belay A, Haki GD, Birringer M, Borck H, Lee YC, Kim KT, Baye K, Melaku S. 2017. Enzyme activity, amino acid profiles and hydroxymethylfurfural content in Ethiopian monofloral honey. J Food Sci Technol 54: 2769-2778. DOI: 10.1007/s13197-017-2713-6.

Bentabol-Manzanares A, García ZH, Galdón BR, Rodríguez ER, Romero CD. 2014. Physicochemical characteristics of minor monofloral honeys from Tenerife, Spain. LWT - Food Sci Technol 55: 572-578. DOI: 10.1016/j.lwt.2013.09.024.

Biluca FC, Bernal J, Valverde S, Ares AM, Gonzaga LV, Costa ACO, Fett R. 2019. Determination of free amino acids in stingless bee (Meliponinae) honey. Food Anal Methods 12: 902-907. https://doi.org/10.1007/s12161-018-01427-x.

Biluca FC, Braghini F, Gonzaga LV, Costa ACO, Fett R. 2016. Physicochemical profiles, minerals and bioactive compounds of stingless bee honey (Meliponinae). J Food Compos Anal 50: 61-69. DOI: 10.1016/j.jfca.2016.05.007.

Bogdanov S, Lüllmann C, Martin P, von der Ohe W, Russmann H, Vorwohl G, Oddo LP, Sabatini AG, Marcazzan GL, Piro R, Flamini C, Morlot M, Lhéritier J, Borneck R, Marioleas P, Tsigouri A, Kerkvliet J, Ortiz A, Ivanov T, D’Arcy B, Mossel B, Vit P. 1999. Honey quality and international regulatory standards: Review by the international honey commission. Bee World 80: 61-69. DOI: 10.1080/0005772x.1999.11099428.

Bogdanov S, Ruoff K, Oddo, LP. 2004. Physico-chemical methods for the characterisation of unifloral honeys: A review. Apidologie 35: 71-81. DOI: 10.1051/apido:2004047.

Chuttong B, Chanbang Y, Sringarm K, Burgett M. 2016. Physicochemical profiles of stingless bee (Apidae: Meliponini) honey from South East Asia (Thailand). Food Chem 192: 149-155. DOI: 10.1016/j.foodchem.2015.06.089.

Da Silva PM, Gauche C, Gonzaga LV, Costa ACO, Fett R. 2016. Honey: Chemical composition, stability and authenticity. Food Chem 196: 309-323. DOI: 10.1016/j.foodchem.2015.09.051.

Dobre I, Georgescu LA, Alexe P, Escuredo O, Seijo MC. 2012. Rheological behavior of different honey types from Romania. Food Res Int 49: 126-132. DOI: 10.1016/j.foodres.2012.08.009. 
Erwan, Astuti M, Syamsuhaidi, Muhsinin M, Agussalim. 2020. The effect of different beehives on the activity of foragers, honey potsnumber and honey production from stingless bee Tetragonula sp. Livest Res Rural Dev 32 (10): 158.

Erwan, Suhardin, Syamsuhaidi, Purnamasari DK, Muhsinin M, Agussalim. 2021. Propolis mixture production and foragers daily activity of stingless bee Tetragonula sp. in bamboo and box hives Livest Res Rural Dev 33 (6): 82.

Escuredo O, Míguez M, Fernández-González M, Seijo MC. 2013. Nutritional value and antioxidant activity of honeys produced in a European Atlantic area. Food Chem 138: 851-856. DOI: 10.1016/j.foodchem.2012.11.015

Guerrini A, Bruni R, Maietti S, Poli F, Rossi D, Paganetto G, Muzzoli M, Scalvenzi L, Sacchetti G. 2009. Ecuadorian stingless bee (Meliponinae) honey: A chemical and functional profile of an ancient health product. Food Chem 114: 1413-1420. DOI: 10.1016/j.foodchem.2008.11.023.

Hermosín I, Chicón RM, Cabezudo MD. 2003. Free amino acid composition and botanical origin of honey. Food Chem 83: 263-268. DOI: 10.1016/S0308-8146(03)00089-X.

Iglesias MT, Martín-Álvarez PJ, Polo MC, De Lorenzo C, González M, Pueyo E. 2006. Changes in the free amino acid contents of honeys during storage at ambient temperature. J Agric Food Chem 54: 90999104. DOI: 10.1021/jf061712x.

Kahono S, Chantawannakul P, Engel MS. 2018. Social bees and the current status of beekeeping in Indonesia. In: Chantawannakul $\mathrm{P}$, Williams G, Neumann P (eds). Asian Beekeeping in the 21 st Century. Springer, Singapore. DOI: 10.1007/978-981-10-8222-1.

Karabagias IK, Badeka A, Kontakos S, Karabournioti S, Kontominas MG 2014. Characterisation and classification of Greek pine honeys according to their geographical origin based on volatiles, physicochemical parameters and chemometrics. Food Chem 146 548-557. DOI: 10.1016/j.foodchem.2013.09.105.

Kečkeš J, Trifković J, Andrić F, Jovetić M, Tešić Ž, Milojković-Opsenica D. 2013. Amino acids profile of Serbian unifloral honeys. J Sci Food Agric 93: 3368-3376. DOI: 10.1002/jsfa.6187.

Kowalski S, Kopuncová M, Ciesarová Z, Kukurová K. 2017. Free amino acids profile of Polish and Slovak honeys based on LC-MS/MS method without the prior derivatisation. J Food Sci Technol 54: 37163723. DOI: 10.1007/s13197-017-2838-7.

Oddo LP, Heard TA, Rodríguez-Malaver A, Pérez RA, Fernández-Muiño M, Sancho MT, Sesta G, Lusco L, Vit P. 2008. Composition and antioxidant activity of Trigona carbonaria honey from Australia. J Med Food 11: 789-794. DOI: 10.1089/jmf.2007.0724

Piazza MG, Accorti M, Oddo LP. 1991. Electrical conductivity, ash, color, and specific rotatory power in Italian unifloral honeys. Apicoltura 7: 51-63.

Ranneh Y, Ali F, Zarei M, Akim AM, Hamid HA, Khazaai H. 2018. Malaysian stingless bee and Tualang honeys: A comparative characterization of total antioxidant capacity and phenolic profile using liquid chromatography-mass spectrometry. LWT - Food Sci Technol 89: 1-9. DOI: 10.1016/j.1wt.2017.10.020.

Rebane R, Herodes K. 2010. A sensitive method for free amino acids analysis by liquid chromatography with ultraviolet and mass spectrometric detection using precolumn derivatization with diethyl ethoxymethylenemalonate: Application to the honey analysis. Anal Chim Acta 672: 79-84. DOI: 10.1016/j.aca.2010.04.014.

Ribeiro RDOR, Mársico ET, Carneiro CDS, Monteiro MLG, Júnior CC, de Jesus EFO. 2014. Detection of honey adulteration of high fructose corn syrup by Low Field Nuclear Magnetic Resonance (LF $1 \mathrm{H}$ NMR). J Food Eng 135: 39-43. DOI: 10.1016/j.jfoodeng.2014.03.009.

Sabir A, Agus A, Sahlan M, Agussalim. 2021. The minerals content of honey from stingless bee Tetragonula laeviceps from different regions in Indonesia. Livest Res Rural Dev 33 (2): 22.

Sak-Bosnar M, Sakač N. 2012. Direct potentiometric determination of diastase activity in honey. Food Chem 135: 827-831. DOI: 10.1016/j.foodchem.2012.05.006.

SNI. 2018. Indonesian National Standard for Honey. Badan Standarisasi Nasional, Jakarta.

Souza B, Roubik D, Barth O, Heard T, Enriquez E, Carvalho C, VillasBoas J, Marchini L, Locatelli J, Persano-Oddo L, Almeida-Muradian L, Bogdanov S, Vit P. 2006. Composition of stingless bee honey: Setting quality standards. Interciencia 31: 867-875.

Suárez-Luque S, Mato I, Huidobro JF, Simal-Lozano J, Sancho MT. 2002. Rapid determination of minority organic acids in honey by highperformance liquid chromatography. J Chromatogr A 955: 207-214. DOI: $10.1016 / \mathrm{S} 0021-9673(02) 00248-0$.

Sun Z, Zhao L, Cheng N, Xue X, Wu L, Zheng J, Cao W. 2017. Identification of botanical origin of Chinese unifloral honeys by free amino acid profiles and chemometric methods. J Pharm Anal 7: 317323. DOI: $10.1016 /$ j.jpha.2017.06.009.

Suntiparapop K, Prapaipong P, Chantawannakul P. 2012. Chemical and biological properties of honey from Thai stingless bee (Tetragonula leaviceps). J Apic Res 51: 45-52. DOI: 10.3896/IBRA.1.51.1.06.

Trianto M, Purwanto H. 2020. Morphological characteristics and morphometrics of stingless bees (Hymenoptera: Meliponini) in Yogyakarta, Indonesia. Biodiversitas 21: 2619-2628. DOI: 10.13057/biodiv/d210633.

Truzzi C, Annibaldi A, Illuminati S, Finale C, Scarponi G. 2014. Determination of proline in honey: Comparison between official methods, optimization and validation of the analytical methodology. Food Chem 150: 477-481. DOI: 10.1016/j.foodchem.2013.11.003.

Villacrés-Granda I, Coello D, Proaño A, Ballesteros I, Roubik DW, Jijón G, Granda-Albuja G, Granda-Albuja S, Abreu-Naranjo R, Maza F, Tejera E, González-Paramás AM, Bullón P, Alvarez-Suarez JM. 2021. Honey quality parameters, chemical composition and antimicrobial activity in twelve Ecuadorian stingless bees (Apidae: Apinae: Meliponini) tested against multiresistant human pathogens. LWT-Food Sci Technol 140: 110737. DOI: 10.1016/j.lwt.2020.110737. 